\title{
The role of negative and positive forms of power in supporting CSR alignment and commitment between Large Firms and SMEs
}

\section{David Harness, Chatura Ranaweera, Heikki Karjaluoto, Chanaka Jayawardhena}

\begin{abstract}
:
Do large firms exert power to shape the CSR behavior of their SME partners?” We answer this question by proposing a model built on the stakeholder theory and the shareholder theory, and go on to explain how this impact influences the commitment of the SME towards their large partner. The model highlights the central role that different forms of power exercised by the large firm play in the process. A survey of 291 SMEs confirms the key hypotheses, including the mediating role of reward power. The effects of coercive power are noteworthy and they illustrate the complex and competing forces at play in influencing CSR behavioral change in SMEs. The research makes a novel contribution to practice by highlighting among other things, how power, as a negative force via coercion or positively through expert or reward benefits, support or becomes counterproductive to the change process.
\end{abstract}

Keywords: CSR Orientation, coercive power, reward power, affective commitment, continuance commitment, normative commitment 


\section{Introduction}

This article explores the relationship between Small to Medium Enterprises (SMEs) and the firms they identify as being their large and most important trading partner from the perspective of corporate social responsibility (CSR). It examines the role of power arising from the asymmetric size of partners in the evolution of CSR in partner organizations; specifically the role played by positive forms of power - reward and expert, and when applied negatively in the form of coercive power. CSR has been identified to differ between large firms and SMEs, in terms of what it is and its motivations for adoption. Large organizations, to protect their reputation, increasingly need to be seen as CSR compliant (Bertels \& Peloza, 2011). To do this, large firms may actively encourage the smaller trading partners to adopt their own social and environmental policies and practices, for example. The adoption of compatible CSR practices by the SMEs is in turn likely to deepen their commitment to the large partner. The extent to which this is the case has yet to be tested empirically and remains an important gap in our understanding of CSR development between trading partners. This study provides new and original insights into the role of CSRO of a large firm, use of power by the large firm towards their SME partners, and the commitment of the SMEs to the large partner firm, as perceived by the SME.

For business leaders CSR is seen as an inescapable priority (Marin et al., 2009), where firms "are expected to look beyond self-interest and recognise that they belong to a larger group, or society, that expects responsible participation” (Thorne et al., 2008, p.4). For this study we take Carroll's (1979, p.500) view that "the social responsibility of business encompasses the economic, legal, ethical, and discretionary expectations that society has of organisations at a given point in time”. The business benefits of CSR adoption are well known, however, the adoption of CSR may reduce a firm's ability to maximise profits and shareholder value 
(Blowfield \& Murray, 2011), reduce operational excellence (van Tulder \& van der Zwart, 2006), and competitiveness (Sims, 2003). This is contrary to "Shareholder theory" which argues that organisations contribute best to the welfare of society by maximising their profitability. Profit enables firms to pay their workforce, suppliers, shareholders and taxes, which provides revenue to the state to deliver social policy (Henderson, 2001; Weyzig, 2009). However, Heath (2006 p.542) stated that managers have "moral obligations, not just to shareholders, but to other groups” and thus questions the underlying emphasis within shareholder theory.

A different emphasis underpins Stakeholder theory in that it accepts there are many groups (different and competing for interest) with the ability to influence and be influenced by the organization. Thus as Guthrie, Petty and Ricceri (2006, p.256) stated "stakeholder theory highlights organizational accountability beyond simple economic or financial performance”. This means firms are required to manage to the benefit of all stakeholders (Freeman, 1994). Success is determined by the nature of the firm's relationship with their stakeholders even if this leads to reduced profitability (Smith, 2003; Phillips, 2003). Stakeholder theory is seen to exist in two forms. The ethical perspective views all stakeholders as having the right to be treated fairly by the organization (Freeman, 1984), whereas the managerial perspectives views that the role of the manager is to meet the expectations of stakeholders who hold critical resources needed by the firm to succeed economically such as partnering SMEs (Philips, 2003). Stakeholder theory differs from shareholder theory in that it places responsibility on the firm to consider how its actions impact on the long term well-being of each stakeholder group (Russo \& Perrini, 2009, p.209). In line with this we expect that a large firm, which is CSR orientated will have to grapple with these competing perspectives, when deciding how to use power to deal with their SME partners, in order to influence change beneficial to the large firm, and potentially to their partner as well. 
Tang and Tang (2012) found some evidence that the relationship between stakeholder CSR orientation influenced SME environmental activity. Whilst their study did not explicitly look at the relationship between a large firm and its SME partners, it promotes the notion that a larger more powerful stakeholder may influence the SME's CSR activity. CSR orientation (CSRO) describes a firm's genuine effort to align its business activities with their social and environmental objectives (Doppelt, 2003; Yuan et al., 2011); a process described as iterative, sequential and multi staged (Dunphy et al., 2003; Van Marrewiki \& Were, 2003). A process where an organization builds on what exists, which in turn constrains its ability to introduce immediate, wholesale and complete CSR orientated change (Castka et al., 2004). Stages towards CSR orientation, for example, include evaluating current CSR activity, developing CSR goals, gaining senior management buy in, gaining employee buy in, prioritizing change effort, measuring progress, anchoring change and adapting change process based on intervening factors and learned experience (for a detailed overview see Lindgreen et al., 2012). Whilst agreement about the stages that firms go through in their journey to CSR orientation is lacking a consistent theme within this is the idea that external stakeholders, which includes suppliers, and distributors such as SMEs, have to buy into the change process for the firm to succeed in becoming CSR oriented (Cramer et al., 2004; Maignan \& Ferrell, 2000). ”Buy in” implies that the SME complies with the CSR business practices of the change driving firm. As such this is recognized as being a long term aspiration, with progress measured over years (Lindgreen et al., 2012). This reflects that each firm's (large or SME) view of CSR may be equally valid but different. This implies that within a trading relationship the social and environmental activities between firm types may be misaligned. Taking a large firm perspective, it seems the need to protect corporate reputation plays a significant role in requiring that trading partners at least meet their CSR policies and 
practices. We contend that the mechanism by which large firms can achieve compliance from SMEs is ultimately concerned with the application of power.

Lindgreen et al. (2009, p.305) noted that power "represents a formidable force that can effectively exclude suppliers from the market place if they appear socially irresponsible”. The role that large partner power plays in influencing SMEs to adopt their version of CSR, is not well understood. From a CSR perspective, how positive and negative forms of power, specifically expert, reward, and coercive, impact the relationship between a dominant firm and their trading partners is unclear. Both expert and reward power are based on giving positive reinforcements to the party that is subject to the use of power, whereas coercive power is essentially negative and is based on some form of threats and the withholding of some resource from the other party. This raises a number of issues. First, we do not understand the role that positive and negative forms of power play in aligning SMEs' CSR policies and practices to those of their dominant partner. We suggest that overall CSRO of the dominant firm influences the power type used. For example, a highly CSR orientated firm would use power in a positive and supportive way, whereas low CSRO might imply greater use of coercive power. Second, the relationship between negative or positive power to shape SMEs behavior and willingness to continue to work with the larger firm is unknown. This matters because organizational CSR capability evolves over time, reflecting an iterative process as firms learn to alter business activities to support social and environmental concerns (Cramer et al., 2004; Porter \& Kramer, 2006). This promotes longer term business relationships operating in a climate where firms learn from each other and adopt mutually beneficial practices, leading to increased commitment between the partners (Morgan \& Hunt, 1994). Such a commitment is likely to encompass all three dimensions of commitment proposed in the literature (Meyer et al., 2002). Specifically, affective commitment, arising from the stronger bond created between the parties through working together towards common objectives; (C) 2018. This manuscript version is made available under the CC-BY-NC-ND 4.0 license http:// creativecommons.org/ licenses/ by-nc-nd/4.0/ 5 
normative commitment, arising from both parties adopting a set of norms that would obligate them to continue working together. Finally, continuance commitment reflects the increased level of difficulty, especially for the smaller partner to leave the relationship due to their commitment of resources e.g. adopting new CSR standards to align with those of its larger partner.

We seek to better understand the dynamics of these three types of power and CSRO between business partners from the SME's perspective, and how the adoption of CSR practices, that are more aligned with those of its large partner, will influence the SME's commitment to the relationship. Our justification is that first, there is limited empirical study of these phenomena and thus, are not well understood. Second, large organizations cannot achieve their CSR objectives without gaining the tangible "buy in" of their existing SMEs. The way in which positive and negative forms of power are used to achieve this may impact on an SME's inclination to adopt the CSR practices of their dominant partner and consequently to their commitment towards the large partner. There is a need to understand how power supports or hinders this process. An exploration of the link between how SMEs perception of the large partner firms' CSRO impacts on their expectation of how they are treated during the alignment process, and how they respond to that process are theoretically valuable. Our approach addresses a major concern highlighted by Homburg et al. (2013, p.3) that knowledge of the development of CSR in a B2B context "is virtually non-existent".

This paper is structured as follows. In the next section we present a review of the literature in this area, and develop the hypotheses and the conceptual model. The research methodology is then explained. We next present the analysis and results of the research. Finally, the paper concludes with a discussion of the results and their implications for academics and practitioners, limitations of the study, and directions for future research. 


\section{Literature Review and Conceptual Development}

Figure 1 presents our conceptual model, illustrating the proposed relationships between large firm CSRO and the three types of power in influencing SME behavioral change, and how that change leads to increased commitment on the part of the SME towards their large partner. The relationships tested in this study, the rationale for linkages between individual concepts and further details of theory used to underpin it are outlined below.

$<$ Take in Figure 1 about here $>$

Figure 1: The conceptual model

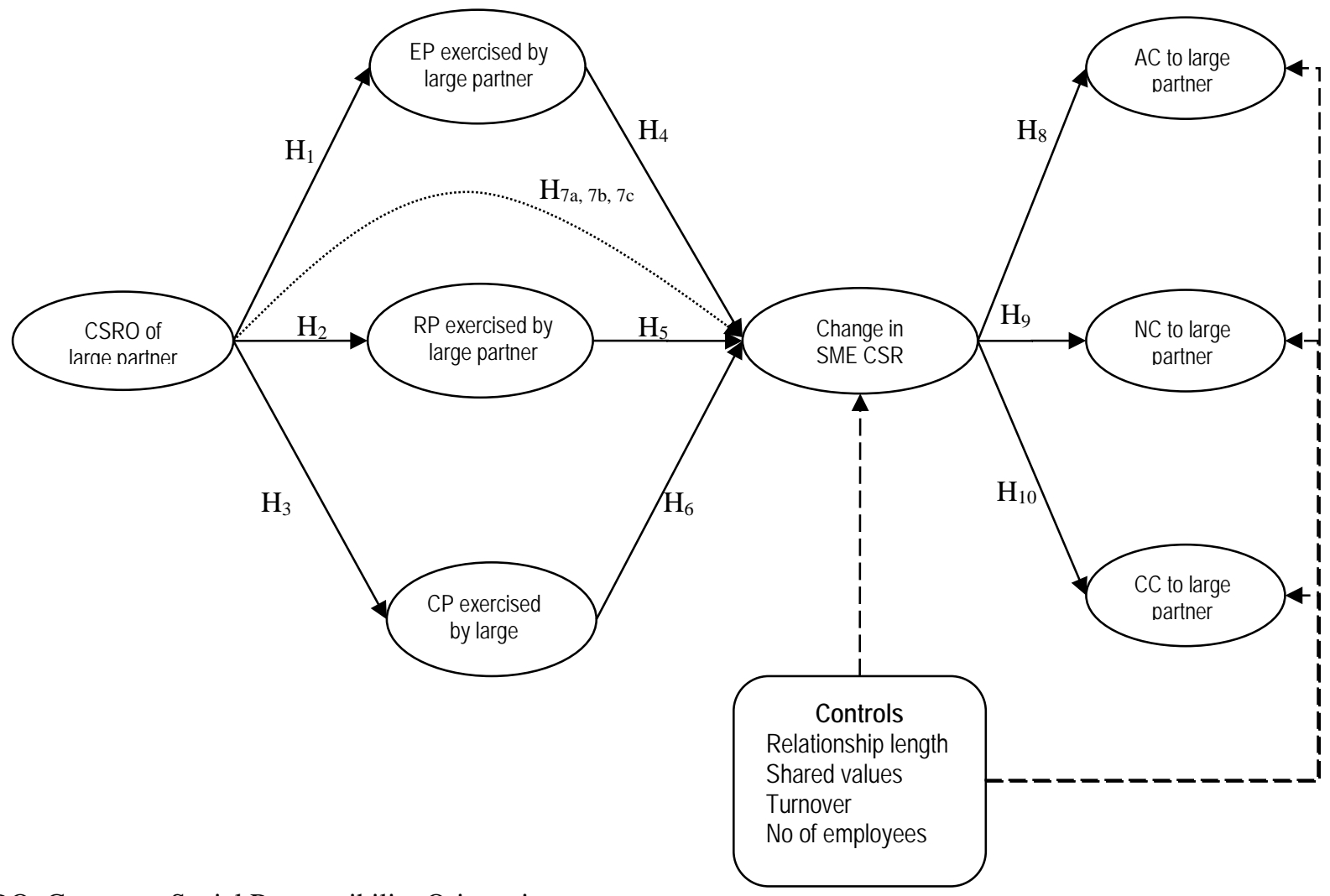

CSRO: Corporate Social Responsibility Orientation

EP: Expert Power

RP: Reward Power

CP: Coercive Power 
AC: Affective Commitment

NC: Normative Commitment

CC: Calculative Commitment

By adopting CSR practices a business indicates that its desire to maximize profit is tempered by its aspiration to do good by contributing economically, undertaking philanthropic activity, and acting responsibly to stakeholders (Carroll, 1999; Weyzig, 2009). We adopt Carroll's (1979, p. 500) conceptualization of CSR based on the concept that "the social responsibility of business encompasses the economic, legal, ethical, and discretionary expectations that society has of organizations at a given point in time”. We believe that our approach of studying SME perceptions is especially appropriate because SME attitudes and behaviors towards their large partner are likely to be dependent on the perceived and not necessarily actual behavior of the large partner firm. Evidence suggests that large firms tend to make their CSR activities transparent to demonstrate commitment and build reputation (Fernandez-Feijoo, et al., 2014; Morhardt, 2010). This information is both in the public domain (Kim \& Park, 2013) and highly accessible to stakeholders (Compopiano \& De Massis, 2015). For SMEs, the views of owner managers, likely to be influenced by awareness of the public CSR stance of their trading partners, is seen as significant in driving their attitude to and level of engagement with CSR (Blombäck \& Wigren, 2008). This was highlighted by Adobar (2011, p.73) who argued that "the adoption of common standards and the development of convergent expectations on collaboration" emerges from a shared value perspective that then "promotes the use of collective strategies".

Based on a review of the power literature, including the seminal work by Raven and French (1958) which identifies sources of social power, as well as more recent critiques, we investigate the mechanisms through which large firms influence SMEs' CSR alignment. Of the five power bases identified by Raven and French, three are central to the current study: Reward 
power, expert power and coercive power. We exclude the other two forms of power in this study because they are not directly related to the context of the investigation. Legitimate power comes from formal authority of one over the other, and this is not present in the current context. Referent power comes from the weaker person identifying with the stronger person. While there is some form of identification on the part of SMEs with the large partner, our focus in this study is on how the large partner uses power to influence the SMEs. Referent power is dependent on SMEs' own identification with its partner, rather than on deliberate actions of the large firm itself, and therefore has no direct relevance to this study.

In marketing relationships, power is the ability of one entity to influence the behaviors and strategies of another (Lederhaus, 1984). While followers of Raven and French formulate their definitions on the basis of power "bases", others see it in terms of influence strategies such as information exchanges, recommendations, requests, promises, threats, and legalistic actions. Both conceptualizations have been subject to some criticism. Especially noteworthy are the findings that the effects of power have not been consistently found (c.f.: Blois \& Hopkinson, 2013 for a detailed discussion). However, there is a strong body of literature which supports the view that a fundamental dichotomy exists between coercive power and non-coercive power (Zhuang et al., 2010). It is this distinction that is salient to the current study. We adhere to this principle and focus on reward power and expert power as the non-coercive power sources. Reward power is the perception by individual P, that agent O can mediate rewards for him (Raven \& French, 1958). This requires the ability to grant another person or entity desired things, or to remove things not desired. Expert power is based on P's perception that O has some special knowledge or expertise (Raven \& French, 1958). The ability to administer to another, information, knowledge or expertise is essential for the exercise of expert power, with those holding power being able to convince others to trust them. Expertise does not have to be genuine - it is the perception of expertise that provides the power base. When one party perceives that another person or entity (c) 2018. This manuscript version is made available under the CC-BY-NC-ND 4.0 license http:// creativecommons.org/ licenses/ by-nc-nd/4.0/ 9 
possesses superior skills or abilities, they award power to that person or entity. Coercive power, on the other hand, is based on P's perception that $\mathrm{O}$ has the ability to mediate punishments for him (Raven \& French, 1958). The main goal of coercion is compliance. This source of power is known to lead to problems of threats and abuse in both inter-personal and inter-organizational relationships. Therefore, each form of power is likely to impact inter-firm relationships, nature of the change process, and willingness of one party to commit to another.

In the context of SME-large partner relationships, the reason for the dominant partner to use power is because SME's understanding of CSR, and how they discharge their social responsibilities, is known to be different to that of a large firm (Spence \& Rutherford, 2003; Preuss \& Perschke, 2009). In this study, we treat the large firm as the dominant and therefore more powerful partner in the relationship. While power can, in some instances, be based on determinants other than size, such as the holding of scarce resources, we believe that the relative size of two partner firms will always have an impact on the power asymmetry. Recent research also highlights how regulations worldwide that allow near monopolies to remain active in business, has made large firms increasingly dominant (Gaspar, 2017).

The aims of a large firm can reflect genuine interest for social and environmental concerns, as well as fear that the actions of a partner can damage the firm's reputation and result in negative customer reaction (Rajaguru \& Matanda, 2011). CSR compliance is said to be gained when the dominant firm's code of conduct, third party certification and labor agreements are accepted by partners (Hietbrink, Berends \& van Rekon, 2010).

From a CSR perspective interaction between firms should be influenced by the principles of stakeholder management theory (Mohr \& Webb, 2005). Blombäck and Wigren (2008, p.259) state that "in essence, stakeholder theory points out that corporations and their stakeholders must exist in alignment to provide wealth for all”. This implies that the relationship between the parties 
is defined by both business needs and social factors. Therefore organizations must manage and meet the interests of various stakeholders, even if they potentially conflict (Thorne et al., 2008). Adherence to Stakeholder theory implies a desire for collaborative activity promoting longer term relationships to enhance value creation, and that power is used in a supportive way (Freeman \& Liedtka, 1997; Myllykangas, Kujala \& Lehtimäki, 2012). The process is likely to be conditioned by whether the large firm adopts a more "managerial stakeholder perspective" or an "ethical stakeholder perspective”. The former suggests the primacy of the business case comparatively to the ethical case.

We earlier identified that the motivations and ability to engage in CSR between large firms and SMEs can differ. Inevitably, this may result in a poor level of fit between partners. We argue that this is central to understanding the role that power has in achieving CSR alignment between partners. We further argue that the type of power used, based on expectations of how they will be managed, will impact SME's willingness to modify their behavior leading to increased commitment to the relationship.

\subsection{The relationship between large firm CSR orientation and type of power used}

The distance in the CSR standards of the two partner firms is likely to create expectations about the magnitude of alignment required. The degree, to which the needs, demands, goals, objectives, and/or structure of one firm are consistent with those of the other, facilitates effectiveness in the relationship. How the SMEs perceive the dominant firm's CSRO is likely to impact this. CSRO is the extent an organization has adopted principles and practices that allow it to operate and be perceived as being CSR based (Vianova, Lozano, \& Arenas, 2008). This may inform the SME about what change is required of them, and how attractive working with the larger firm could be. CSRO places responsibility on the large firm to manage partners in a way 
that is complimentary to their social aspirations as well as commercial needs (Carter \& Jennings, 2004).

From a different perspective to this study, support for the influence of stakeholder CSRO on the behaviour of SMEs was identified by Tang and Tang (2012). They examined how the government, competitors, customers and media stakeholders used power to encourage social and environmental compliance in China. Their interest lay in the role of net-power i.e. "the net difference between a stakeholder's power over a firm and a firm's countering power to this stakeholder, which determined how the stakeholder was able to pressure firms to engage in environmental activities” (p.436). They combined coercive, and reward power into a single scale. This makes it difficult to determine if the influence identified was based on a positive or negative use of power. This we believe remains an unexplored gap. Further, whilst their study offers some intriguing insights, the relationship between the SME and a large firm, which is the focus of this study, remains unclear.

Our expectation is that CSR orientated firms are more likely to deploy positive forms of power (reward and expert) rather than coercive power. In that case the dominant partner seeks to work through collaborative activity, sharing decision making for mutual gain with other parties and is in keeping with stakeholder theory. It also reflects a moral dimension where "powerful buyers have a duty to create a climate that forces or encourages their suppliers to adhere to responsible practices” (Amaeshi et al., 2006, p.157). However, the weight of evidence suggests that in general, coercive power is used more (Lindgreen et al., 2009). For example, Theyel and Hofman (2012) find that firms exert pressure on suppliers to demonstrate CSR practices either as a pre-condition for tendering or as a complimentary variable in their evaluation of suppliers. Whilst Frooman (1999) highlights the role of power from a resource control perspective in 
discontinuing work to force behavioral change, or to continue with the relationship, but with conditions.

There is pressure on large firms to be seen to pursue policies linked to CSR (Jenkins, 2009; McWilliams, Siegal, \& Wright, 2006). It also indicates some firms may be perceived as CSR orientated, whereas in reality, business case logic remains the driver of activity rather than stakeholder concepts. Therefore, it is likely that the type of power deployed will be related to the sincerity of a firm's CSR activities and thus their actual depth of orientation. Consequently, the greater a firm's CSRO, the more it will select positive forms of power and less of negative power. Therefore:

$H_{1}$ : The greater the CSRO of the large partner firm, the greater the exercise of expert power $\mathrm{H}_{2}$ : The greater the CSRO of the large partner firm, the greater the exercise of reward power $\mathrm{H}_{3}$ : The greater the CSRO of the large partner firm, the lower the exercise of coercive power

1.

2. The relationship between power form exercised and change in SME CSR behavior

While a firm's CSRO will influence their selection of power type, the decision, we believe, will be determined by the potential of the method chosen to gain SME behavioral change. From a dominant firm's perspective, their selection of power may be based on past experience of working with the SME, their timescales for change and level of managerial and resource commitment available (Sethi et al., 2010). Coercive power, which we term negative power, can take many forms. It can involve withholding resources from the partner causing them to be constrained from some action, or it can involve forcing a certain action that the partner 
would otherwise not have engaged in. Selecting coercive power usually happens when the other party ignores or pretends to ignore a problem concerning the relationship, and demonstrates poor results, or adopts non-compliant behavior (Leonidou et al., 2008). Coercive power is known to be effective if immediate action is necessary, when or delays can lead to danger, or where there is no time for negotiation (Coser, 1956). Thus, whilst its use may be effective in the short term in forcing certain actions or inactions by the partner, it's more likely to escalate tensions in the relationship, leading to long term negative consequences (Leonidou et al., 2008). This indicates that use of coercion is not optimal in long term partner relationships where there is opportunity for discussion and negotiation. Coercive power is also known to involve a "negative-sum game", meaning that either both parties lose or, the winner's gain is less than the opponent's loss (Boulding, 1989). In this context, the SME may react negatively to the use of coercive power, especially if termination of the relationship is implied by the large partner. We therefore posit that the application of coercive power is less likely to result in SME CSR alignment with the large partner.

We expect positive power to have a different impact on SME change behavior. The adoption of CSR by any firm has to be at a philosophical level embedded into the firms' DNA to inform all its commercial activities. This requires the SME to direct its scarce resources to further its CSR ambitions. Conditioning this will be the overriding motives of the SME to want to change, which may range from commercial survival to a deeply held belief that it is the right thing to do (Barabel \& Meier, 2012). Reward power supports the SMEs business imperative by ensuring it gains materialistically from behavioral change. Expert power, for example through knowledge transfer, enables the SME to learn how to satisfy the CSR needs of the dominate partner, and gain a wider appreciation of the issues faced in CSR adoption. In both these 
situations it is expected that positive power will serve to encourage SMEs to change their behavior with regards to CSR to be more aligned with that of the large partner. Therefore:

$\mathrm{H}_{4}$ : The greater the exercise of expert power, the greater the change in SME CSR behavior $H_{5}:$ The greater the exercise of reward power, the greater the change in SME CSR behavior $H_{6}$ : The greater the exercise of coercive power, the lower the change in SME CSR behavior

\subsection{Mediating Effects of the different forms of Power}

We propose that the direct effect of CSRO of the large organizations on change in SME's CSR behavior will be mediated by the three sources of power that the former exercises over the latter. Reasons why the CSRO of large organizations could be directly related to change in SME's CSR behaviour can be identified. We would expect that an SME which perceives its dominant partner to be strongly CSR orientated is more likely to change its own CSR behavior than a firm working with a larger partner, not perceived as CSR oriented. For SMEs operating in an uncertain environment of changing trends towards CSR, the tendency to display similar behavior to those of their large partners is likely to be appealing.

Underpinning the need for alignment is caused by the type of CSR undertaken by large firms and SMEs. This is because the emphasis each places on social and environment activities is different. Perrini, Russo and Tencati (2007) identified CSR strategies used by Italian SMEs and large firms. They found that "size explains the difference in a firm's willingness to define and implement such specific CSR strategies since formal CSR approaches still seem to be the prerogative of large firms" (p.293). Further they argue that "the mainstreaming of CSR needs to 
be strongly promoted by those firms that have already experienced CSR strategies, and they now must transfer such competitive and social advantage along the supply chain” (p.294). This seems to imply that the lead is taken by the larger firm through collaboration and reward to gain CSR strategy alignment. However, the mechanisms of how this might take place, and specifically the role of large firm power within their study, is untested and provides a clear point of difference between their work and focus of this study.

More recently Lauda (2011, p.139) noted that "SMEs are unlikely to see CSR in terms of risks to public reputation and brand image. They are often likely to follow sentiments closer to home such as employer motivation and retention, and community involvement”. Further differences relate to firm size, managers' social economic model; competitive impact; innovation possibilities; desire to differentiate; legal regulation; and firm visions/mission (Granovetter, 2005; Murillo \& Lozano, 2006); place within a community, local knowledge, and resource scarcity (Spence \& Rutherford, 2003; Preuss \& Perschke, 2009). Cambra-Fierro et al. (2008) note that while some firms take socially responsible actions in a purely altruistic way, most intend to obtain an economic profit from the management system or the effort to implement it, so that profit and social responsibility may be combined. This may explain why SMEs promote an image of CSR activity rather than actually "doing it” (Crane, 2001). SMEs' motives to engage with CSR are wide and determined greatly by what type of social activities they consider valid. These may not be the same or even compatible with those of their partners (Preuss \& Perschke, 2009). It is in this context that a direct association of CSRO of the large firm and the SMEs CSR behavioral change may be overly simplistic. Rather, some form of influence on the part of the large partner firm is likely to be a necessary condition to engender change on the part of the SMEs. Such influence is likely to come from the sources of power that large firms hold, both 
positive and negative. This illustrates that the effect of CSRO of the large partner on SME CSR behavioral change may happen because of the exercise of power on the part of the former. This suggests that power mediates the above mentioned direct association. Specifically;

$H_{7}$ : CSR orientation of the large partner will have a positive influence on the change in SME CSR behavior. However, this effect will be mediated by:

a) the exercise of expert power by the large partner $\left(\mathrm{H}_{7 a}\right)$

b) the exercise of reward power by the large partner $\left(\mathrm{H}_{7 b}\right)$

c) the exercise of coercive power by the large partner $\left(\mathrm{H}_{7 c}\right)$

\subsection{Effects of SME's CSR Behavioral Change on their Commitment to Partner Firm}

Having offered the conceptual basis for the way the exercise of power by large partners can lead to SME CSR behavioral change, we now focus on the outcome of such behavioral change. We propose that the SMEs behavioral change process, as a result of their relationship with their large partner, will lead to an increase in their overall commitment to the partner firm. Commitment to a relationship in general is known to be driven by among other things, relationship benefits, relationship termination costs and shared values (Morgan \& Hunt, 1994). The alignment of CSRO between the large firm and the SME is likely to be characterized by all three of these factors. First, such an alignment is likely to be mutually beneficial for a long term partnership. Second, such an alignment, resulting from significant effort on the part of the parties, will create significant costs associated with terminating the relationship built over time with commitment of resources. Finally, the shared CSRO will broadly constitute shared values between the partner organizations. Consequently, the process of change that the SME went 
through in order to be aligned with the CSRO of the large partner will lead to an overall increase in commitment.

Commitment is a psychological state that characterizes one party’s relationship with another, influencing the decision to continue or discontinue the relationship (Meyer \& Allen, 1997). Commitment is of three types - affective, normative and continuance, each clearly distinguishable (Meyer \& Allen, 1991). Affective commitment denotes an emotional attachment to, identification with, and involvement in another entity. Continuance commitment denotes the perceived costs associated with leaving the relationship with the entity (Meyer \& Allen, 1984). Normative commitment reflects a perceived obligation to remain in the relationship (Allen \& Meyer, 1990). Bansal, Irving, and Taylor (2004) in a B2C context elaborated on these: Affective commitment is a desire-based attachment to the organization; they remain in the relationship because they want to. Normative commitment is an obligation-based attachment; they remain in the relationship because they ought to; and it is the right thing to do. Continuance commitment is a cost-based attachment where one feels one has to stay in the relationship; they remain in the relationship because they need to or have little choice but to.

The literature shows that the three types of commitment have somewhat distinct antecedents. Meyer et al. (2002) in a meta-analysis of employees' commitment to their organization identified a key set of such characteristics. Of these, we believe that while some are unique to an employee-employer relationship, others are generalizable to inter-firm relationships.

The nature of the experience with the partner firm forms the crux of the first set of characteristics (Meyer et al., 2002). Where the experience is positive, such experience is likely to generate good will towards the partner and a desire to further strengthen the affective nature of the relationship. During the process of changing their behavior towards CSR implementation, the SMEs will go through a series of interactions with their large partner. Drawing upon the work of (C) 2018. This manuscript version is made available under the CC-BY-NC-ND 4.0 license http:// creativecommons.org/ licenses/ by-nc-nd/4.0/ 18 
Meyer and Allen (1997) in employee-firm relationships, we suggest that during these interactions, among other things, the SMEs will end up attributing certain outcomes to certain actions by their partner; they will end up rationalizing certain actions by their partner; they will make evaluations of how their expectations were met, and consequently, how satisfied they were with the outcome; and they will end up evaluating their fit with their large partner. Where the Gestalt view of these evaluations is positive, the SMEs relationship with their partner may strengthen. The greater the positive change process they go through, the stronger the relationship will be. This process of change is likely to strengthen affective commitment towards the partner.

Adapting Meyer et al.’s (2002) commitment framework, we propose that the nature and scope of investment SMEs undertake in the change process form the crux of the second set of characteristics. CSR behavioral change requires investment of resources, changes to business practices, embedding new processes, etc. Once such investments are made, influenced by the larger partner, the SMEs are likely to be interested in the long term safeguarding their investment. Any loosening in the relationship is likely to put the investments at risk. As such, the cost of potential risk to their investment arising from having implemented change is likely to tie the SME more firmly to their large partner, increasing their level of continuance commitment to the partner.

Finally, adapting from the aforementioned framework by Meyer and his colleagues (2002), we also argue that the final set of characteristics forming the basis for the SMEs' increased commitment comes from their obligations to the large partner. The effort and influence exerted by the large partner firm in affecting perceived positive change on the part of the SME is likely to make them feel obligated towards the partner and the relationship, increasing their level of normative commitment. 
While contextual considerations will determine the relative weight on each dimension, the behavioral change process undertaken by the SME to embrace the CSR values and policies of the larger firm will result in an overall escalation of commitment on all three dimensions. Consequently, we propose that:

$H_{8}$ : The greater the change in SME CSR behavior, the greater their affective commitment to their large partner

H9: The greater the change in SME CSR behavior, the greater their continuance commitment to their large partner

$H_{10}$ : The greater the change in SME CSR behavior, the greater their normative commitment to their large partner

\subsection{Control variables}

In addition to the formal hypotheses presented above, we also incorporated a set of control variables that can plausibly impact the change in SME CSR behavior, as well as commitment. Firstly, effective change takes time to implement. Thus, behavioral change is more likely in the context of a longer relationship between the SME and the large partner firm. This implies that relationship duration can affect CSR change. Previous literature supports the notion that in long term relationships, firms make changes that increase their commitment to partners. As such, controlling for relationship duration is deemed important. Secondly, for the SMEs, the level of congruency or shared values between their CSR views and those of their large partner firm are known to inform them as to how much change they will undertake. This may be seen as the cost of doing business, or as an opportunity to learn. Irrespective of the reason, this indicates that it is important to control for the effects of shared values. We also include two contextual 
characteristics to capture the size of the SME. Therefore, in this study we specifically control for the following for their potential effects on change in SME CSR behavior and commitment: Relationship duration; shared values between the two firms; turnover of the SME; and the number of employees working for the SME.

\section{Research Method}

To empirically test the hypothesized relationships, we collected data through a survey of SMEs in Finland. The Finnish context was selected as an environment where the progressive alignment of CSR practices between large firms and their SME trading partners is noted to have taken place (Kotonen, 2009), over a number of years (Panapanaan et al., 2003). The strategic level alignment is known to take place as an iterative process over decades. SMEs were defined as per EU recommendation 2003/361 in terms of number of employees $(<250)$ and turnover $(\leq$ EUR 50 million). Respondents e-mail addresses were acquired from an electronic database listing Finnish SMEs from central Finland. We sent out 3153 e-mail invitations to participate in the survey. It was observed that the survey was visited 392 times, and 291 responses were received resulting in an effective response rate of 74.2 percent. In relation to the number of email invitations sent, the response rate was 9.2 percent, generally considered sufficient in B2B research (Larson, 2005). The questionnaire was initially developed in English and then translated into Finnish. To avoid translation errors, the questionnaire was back-translated into English by a different researcher, the two versions compared, and the minor inconsistencies resolved (Mullen, 1995). The survey was pre-tested with nine potential respondents. The pre-test suggested only a change in the order of some of the items and minor changes in wording. We conducted nonresponse bias analysis utilizing a time-trend extrapolation test, and $t$-tests comparing early and

late respondents (c.f.: Armstrong \& Overton, 1977, who treated late respondents as similar to 
non-respondents). The $t$-tests were found to be non-significant at the 0.05 level for all the key constructs, indicating probable lack of non-response bias.

$<$ Please take in Table 1 about here $>$ 
Table 1: Demographic profile of the respondents

\begin{tabular}{|c|c|c|}
\hline & $\mathrm{N}$ & $\%$ \\
\hline \multicolumn{3}{|l|}{ Gender } \\
\hline Female & 86 & 29.6 \\
\hline Male & 205 & 70.4 \\
\hline \multicolumn{3}{|l|}{ Respondent's age } \\
\hline 36 or below & 37 & 12.7 \\
\hline $37-50$ & 109 & 37.5 \\
\hline 51 or more & 145 & 49.8 \\
\hline \multicolumn{3}{|l|}{ Position } \\
\hline Top management & 160 & 55.0 \\
\hline Middle management & 74 & 25.4 \\
\hline Marketing/Sales/Communications & 27 & 9.3 \\
\hline Other & 30 & 10.2 \\
\hline \multicolumn{3}{|l|}{ History in the company } \\
\hline Less than 5 years & 47 & 16.2 \\
\hline $6-10$ years & 59 & 20.3 \\
\hline More than 10 years & 185 & 63.6 \\
\hline \multicolumn{3}{|l|}{ Company's main field of business } \\
\hline Retail & 45 & 15.5 \\
\hline Services & 100 & 34.4 \\
\hline Industrial & 106 & 36.4 \\
\hline Other & 40 & 13.7 \\
\hline \multicolumn{3}{|c|}{ Did you evaluate your supplier or B2B customer? } \\
\hline Supplier & 167 & 57.4 \\
\hline B2B customer & 124 & 42.6 \\
\hline \multicolumn{3}{|c|}{ How long have you co-operated with this partner in question? } \\
\hline Less than 5 years & 79 & 27.1 \\
\hline $5-10$ years & 78 & 26.8 \\
\hline $11-20$ years & 86 & 29.6 \\
\hline 21 years or more & 48 & 16.5 \\
\hline \multicolumn{3}{|l|}{ Who are your main customers? } \\
\hline Consumers & 87 & 29.9 \\
\hline Other companies & 177 & 60.8 \\
\hline Non-profit organizations & 27 & 9.3 \\
\hline \multicolumn{3}{|c|}{ How long has your company been in business? } \\
\hline Less than 10 years & 53 & 18.2 \\
\hline $10-20$ years & 50 & 17.2 \\
\hline More than 20 years & 188 & 64.6 \\
\hline \multicolumn{3}{|l|}{ Company's turnover (millions $€$ ) } \\
\hline Below 0.5 & 79 & 27.1 \\
\hline $3-10$ & 49 & 16.8 \\
\hline $11-20$ & 63 & 21.6 \\
\hline $21-100$ & 49 & 16.8 \\
\hline 101 or more & 51 & 17.5 \\
\hline \multicolumn{3}{|l|}{ Company's number of employees } \\
\hline $1-2$ & 57 & 19.6 \\
\hline $3-10$ & 48 & 16.5 \\
\hline $11-20$ & 45 & 15.5 \\
\hline $21-100$ & 63 & 21.6 \\
\hline 101 or more & 78 & 26.8 \\
\hline
\end{tabular}

(C) 2018. This manuscript version is made available under the CC-BY-NC-ND 4.0 license http:// creativecommons.org/ licenses/ by-nc-nd/4.0/ 23 
Respondent characteristics are shown in Table 1. The sample included micro, small, and medium-sized firms that were not part of a government sponsored partner relationship, and had a single large partner they could identify. Slightly over half of the firms (55.9\%) had a turnover equal or larger than EUR 11 million. Majority of the firms had been in business 10 years or more (81.8\%) and were B2B companies (60.8\%). Slightly over one third (36.4) were industrial companies, around one third (34.4\%) service companies, and 15.5\% retailers. Most of the informants were male (70.4\%) and held a management position (55\% top management, 25.4\% middle management). Half were aged 51 or more (49.8\%) and a majority working in the company for over 10 years (63.6\%). A slight majority (57.4\%) evaluated their supplier in the survey (42.6\% evaluated B2B customer). The vast majority had co-operated with the partner in question for more than five years (72.9\%). This indicates that key informants held enough experience with the company they represent as well with the partner they evaluated. This also meant that most of the firms were not start-ups, which might have access to specialised resources potentially making them more powerful than their large partners.

Measures for the constructs were adapted from prior studies. In brief, measures and their sources are as follows: CSRO of the large partner firm (Turker, 2009); how firms exercise expert power (Sahadev, 2005) reward power (Bigné et al., 2002) and coercive power (Leonidou et al., 2008); change in SME CSR behavior (Lindgreen et al., 2009), and SMEs affective, continuance \& normative commitment to their large partner (Bansal et al., 2004), Respondents were asked to assess all the items (except change in SME CSR behavior), using a 7-point Likert scale, ranging from “1 - strongly disagree” to “7 - strongly agree”. The Likert scale items for the change in SME CSR behavior were labeled "1 - no effect” and "7 - very high effect”. CSRO of the large partner firm and change in SEM CSR behavior were modeled with a hierarchical formativeformative type second order factor structure (see Hair et al., 2013, p.231). The remaining 
constructs were reflective first order constructs. We used four covariates as controls: respondent's company turnover, number of employees, shared values and relationship length with the partner. Company turnover and number of employees are predictors of company's size, which has been identified as an important control in B2B research (Benson, Dickinson, \& Neidt, 1987). We asked the respondents to list "company's turnover" and "number of employees" on a five-point scale (see Table 1). In measuring shared values between the two firms, we adopted two items used in Morgan and Hunt (1994). Relationship length with the partner is an important covariate in B2B studies (Aulakh \& Gencturk, 2000), and was operationalized by assessing the length of the co-operation period with the partner in question.

We apply SmartPLS2.0 (Ringle, Wende, \& Will, 2005) to test the hypotheses, which enables single and multi-item measurement and the use of both reflective and formative scales (Fornell \& Bookstein, 1982; Hair et al., 2012). As a distribution-free method, PLS has fewer constraints and statistical specifications than covariance-based techniques (Hennig-Thurau, Henning, \& Sattler, 2007).

\subsection{Results}

The scales were first subjected to a series of exploratory factor analyses. Principal axisfactoring with varimax rotation showed that most items loaded heavily on the factors they were intended to and confirmed the hypothesized dimensionality of the study constructs. Specifically, the factor analysis revealed a three-factor structure for Change in CSR behavior (explaining 66\% of the variance). These dimensions captured items related to (a) relations inside and outside the SME, image, reputation and economic benefits (b) relations with local community, and (c) CSR reporting and codification. 
The formative constructs in the model were evaluated by assessing indicator weights and outer loadings, and their significance (Hair et al., 2013, pp.150-161). In addition, test of collinearity was conducted. The significance of outer weights was assessed by bootstrapping. First, we assessed the weights and loadings for the lower-order components that captured the subdimensions (e.g. Management believe) of the higher order component (e.g. CSRO). For the lower-order components we found that all formative indicators were significant except four (see Table 6). For the higher-order components, four were not significant. However, as all the outer loadings for the indicators were high (for the lower-order component lowest loading has a value of 0.713$)$ and highly significant $(p<0.01)$ and the indicators are theoretically derived (e.g. Lindgreen et al., 2009; Turker, 2009), based on recommended practice, we retain the indicators in the formative constructs even though their outer weights are not significant (Hair et al., 2013, p.161). In terms of collinearity, it did not reach critical levels as all the Variance Inflation Factor (VIF) results were considerably below 5. Thus, multicollinearity is not an issue for the estimation of the model.

In evaluating the reflective constructs, the following steps were taken to ensure reliability and validity. The high factor loadings ( $\geq 0.712$, see Table 6$)$ and the internal reliability of the scales were above the recommended standards. All constructs presented high composite reliabilities $(\geq 0.831)$ and Cronbach's alpha demonstrated reliability equal to or greater than the recommended value of 0.70 (Nunnally \& Bernstein, 1994) for all other constructs except for NORMCOM (0.697). However, as the value is nearly equal to the cut-off value and its composite reliability is high, and as the scales are those that have been used in prior literature, we believe this does not threaten the reliability of the scale. Analysis of the Fornell-Larcker criterion (1981), which is based on the premise that a latent variable should better explain variance of its own 
indicators than variance of other latent variables, offered strong support for discriminant validity (see Table 2).

$<$ Please take in Table 2 about here $>$

Table 2: Average Variance Extracted (AVE), Reliabilities, Construct correlations, square root of AVE on the diagonal, Means and Standard deviations

\begin{tabular}{|c|c|c|c|c|c|c|c|c|c|c|c|c|c|c|}
\hline & AVE & CR & (1) & (2) & (3) & (4) & (5) & (6) & (7) & (8) & (9) & (10) & (11) & (12) \\
\hline $\begin{array}{l}\text { CSR } \\
\text { orientation (1) }\end{array}$ & $n a^{a}$ & $n a^{a}$ & $n a^{a}$ & & & & & & & & & & & \\
\hline $\operatorname{EXPE}(2)$ & 0.714 & 0.882 & 0.500 & 0.845 & & & & & & & & & & \\
\hline REVA (3) & 0.658 & 0.852 & 0.350 & 0.355 & 0.811 & & & & & & & & & \\
\hline COER (4) & 0.713 & 0.882 & $\begin{array}{c}- \\
0.096\end{array}$ & -0.199 & 0.400 & 0.844 & & & & & & & & \\
\hline $\begin{array}{l}\text { Change in CSR } \\
\text { behavior (5) }\end{array}$ & $n a^{a}$ & $\mathrm{na}^{\mathrm{a}}$ & 0.509 & 0.416 & 0.601 & 0.117 & $\mathrm{na}^{\mathrm{a}}$ & & & & & & & \\
\hline AFFCOM (6) & 0.812 & 0.929 & 0.446 & 0.418 & 0.493 & $0.043 \mathrm{~ns}$ & 0.574 & 0.901 & & & & & & \\
\hline NORMCOM (7) & 0.622 & 0.831 & 0.471 & 0.359 & 0.544 & 0.151 & 0.579 & 0.660 & 0.789 & & & & & \\
\hline CONTCOM (8) & 0.686 & 0.867 & 0.219 & 0.157 & 0.410 & 0.326 & 0.311 & 0.320 & 0.520 & 0.829 & & & & \\
\hline $\begin{array}{l}\text { Shared values } \\
\text { (9) }\end{array}$ & $n a^{b}$ & $n a^{b}$ & 0.035 & $0.085 n s$ & $0.015 \mathrm{~ns}$ & $0.002 \mathrm{~ns}$ & 0.069 & $0.092 \mathrm{~ns}$ & 0.030 & -0.065 & na & & & \\
\hline Turnover (10) & $n a^{b}$ & $n a^{b}$ & $\begin{array}{c}- \\
0.085\end{array}$ & $0.106 n s$ & $\begin{array}{c}- \\
0.036 \mathrm{~ns}\end{array}$ & $\begin{array}{c}- \\
0.069 \mathrm{~ns}\end{array}$ & $\begin{array}{c}- \\
0.008\end{array}$ & $0.023 n s$ & $\begin{array}{c}- \\
0.105\end{array}$ & -0.064 & $\begin{array}{c}- \\
0.030 \mathrm{~ns}\end{array}$ & na & & \\
\hline $\begin{array}{l}\text { No of } \\
\text { employees (11) }\end{array}$ & $n a^{b}$ & $n a^{b}$ & $\begin{array}{c}- \\
0.107\end{array}$ & $0.057 \mathrm{~ns}$ & $\begin{array}{c}- \\
0.051 \mathrm{~ns}\end{array}$ & $\begin{array}{c}- \\
0.026 \mathrm{~ns}\end{array}$ & $\begin{array}{c}- \\
0.015\end{array}$ & $\begin{array}{c}- \\
0.015 \mathrm{~ns}\end{array}$ & $\begin{array}{c}- \\
0.141\end{array}$ & $\begin{array}{c}- \\
0.050 \mathrm{~ns}\end{array}$ & $\begin{array}{c}- \\
0.029 \mathrm{~ns}\end{array}$ & 0.919 & na & \\
\hline $\begin{array}{l}\text { Relationship } \\
\text { length (12) }\end{array}$ & $n a^{b}$ & $n a^{b}$ & 0.081 & 0.165 & 0.142 & $0.066 \mathrm{~ns}$ & 0.133 & 0.259 & 0.160 & 0.288 & $\begin{array}{c}- \\
0.093 \mathrm{~ns}\end{array}$ & 0.246 & 0.223 & na \\
\hline Means & & & 4.86 & 5.15 & 4.34 & 3.38 & 4.39 & 4.45 & 4.24 & 3.98 & $n a^{c}$ & $n a^{c}$ & $n a^{c}$ & 13.34 \\
\hline s.d. & & & 0.93 & 1.56 & 1.62 & 1.88 & 1.17 & 1.49 & 1.66 & 1.87 & $n a^{c}$ & $n a^{c}$ & $n a^{c}$ & 11.04 \\
\hline $\begin{array}{l}\text { Notes: } \\
\text { ns - not signi } \\
\text { CR = Compo } \\
\text { a Not applica } \\
\text { computed. } \\
\text { b Not applica } \\
\text { be computed } \\
\text { c Not applica } \\
\text { or five-noint }\end{array}$ & $\begin{array}{l}\text { icant } \\
\text { site Re } \\
\text { ble. F } \\
\text { ble. C } \\
\text { ble. M }\end{array}$ & ormati & $\begin{array}{l}\text { ve-forn } \\
\text { t meas } \\
\text { d stan }\end{array}$ & $\begin{array}{l}\text { native ty } \\
\text { ured thr } \\
\text { dard dev }\end{array}$ & $\begin{array}{l}\text { pe hier } \\
\text { pugh a } \\
\text { iations }\end{array}$ & $\begin{array}{l}\text { chical } \\
\text { igle inc } \\
\text { t calcu }\end{array}$ & ted fo & $\begin{array}{l}\text { cont mo } \\
\text { compos the co }\end{array}$ & $\begin{array}{l}\text { el; CR } \\
\text { e relia } \\
\text { rols m }\end{array}$ & $\begin{array}{l}\text { bility a } \\
\text { beasure }\end{array}$ & $\begin{array}{l}\text { AE can } \\
\text { on thre }\end{array}$ & pt be & & \\
\hline
\end{tabular}

There is potential for common method bias with all self-reported data (Podsakoff, MacKenzie, Lee, \& Podsakoff, 2003). We enforced a number of procedural remedies at the data collection stage to minimize such bias: Item ambiguity is reduced and the items were mixed in the questionnaire. Respondent identity is kept confidential. We then performed statistical analyses to assess the severity of common method bias. First, we examined common method 
variance bias with Harman's (1967) one factor test. Results from this test show that measurement model factors are present and the most variance explained by one factor is $13.1 \%$, indicating that common method bias is not a likely contaminant of our results. Second, in the data analysis stage, following Podsakoff et al. (2003) and Liang, Saraf, Hu, and Xue (2007), we ran a PLS model with a common method factor whose indicators included indicators of all the principal constructs and calculate each indicator's variance as substantively explained by the principal construct. This analysis showed that average variance substantively explained variance of the indicators (.739), while the average method based variance is .027. It is also showed that most method factor coefficients are not significant. Given the magnitude and the insignificance of method variance, common method bias is unlikely to be of major concern for this study.

In order to estimate paths between the latent variables, a path-weighting scheme is utilized, being the only weighting scheme that explicitly considers the conceptual model directions of the causal relationships between exogenous and endogenous variables (Chin, 1998). Following common conventions, the abort criterion for the iterative estimation process is a change of the estimated values of just $10^{-5} \%$ between two iterations. In order to determine the significance of each estimated path, a standard bootstrapping procedure is applied with 5000 resamples consisting of the same number of cases as in the original sample (Yung \& Bentler, 1996). Table 3 shows the results of the PLS path model1. The model moderately explains the $R^{2}$ of the four outcome constructs. The $R^{2}$ values are moderate $\left(R^{2} \geq 0.368\right)$ for change in SME behavior, affective commitment, and normative commitment; and is small for continuance commitment $\left(R^{2}=0.177\right)$. With respect to control variables, turnover and shared values have no effect on change in SME behavior or commitment.

$<$ Insert Table 3 about here $>$

1 The PLS path model was estimated using latent variable scores in a two-stage approach (Henseler \& Chin, 2010) in which the obtained latent variable scores from the first stage served as manifest variables in the measurement model and in the PLS-path model in the second stage. 
Table 3: The direct effects model

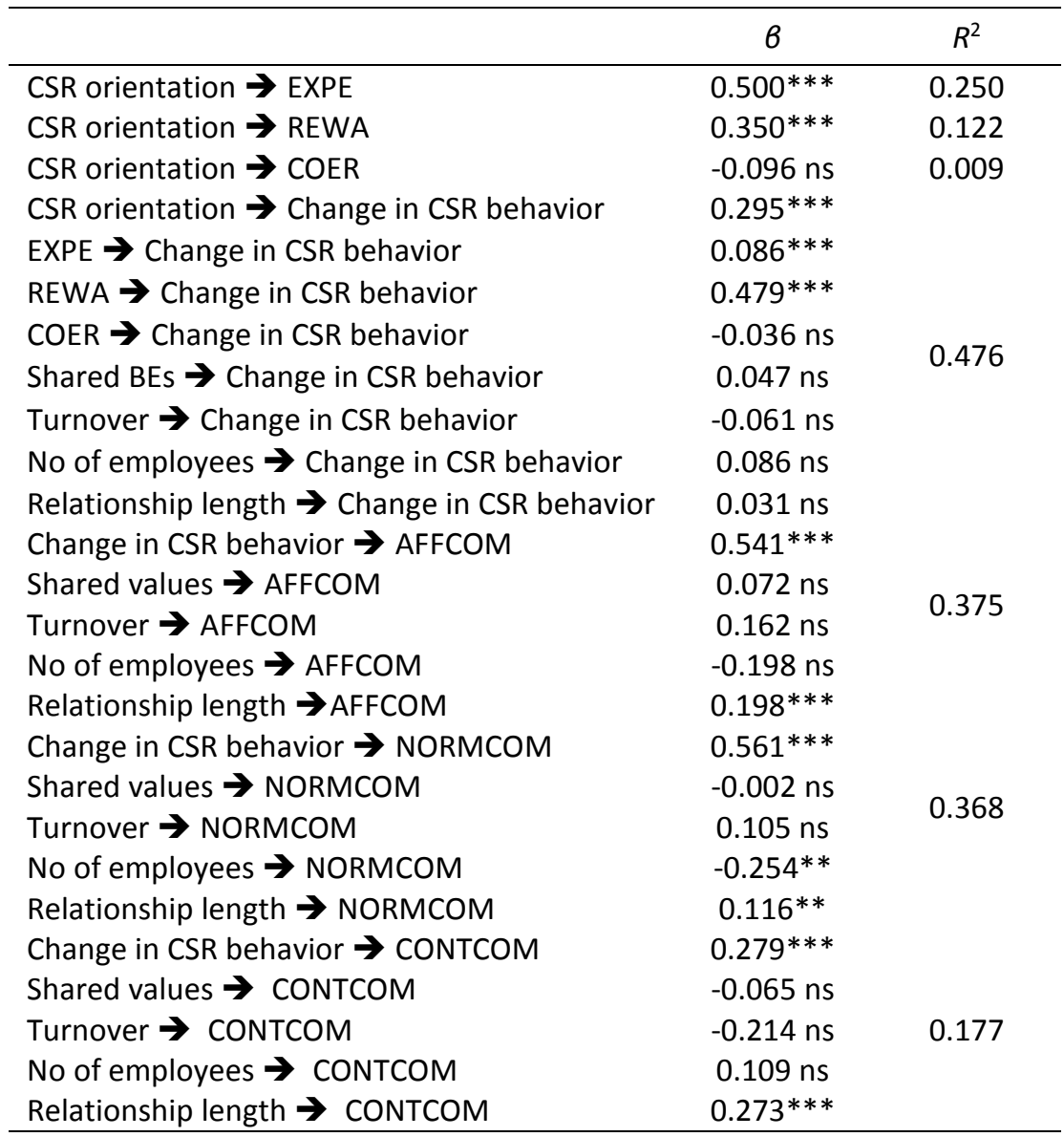

In examining the total effects, there is further evidence that CSRO has a significant total effect on affective commitment (0.275), normative commitment (0.285) and continuance commitment (0.142). Of the power constructs, reward power has the largest total effect on normative commitment (0.269), affective commitment $(0.260)$, and continuance commitment (0.134). The total effect of expert power and coercive power on the three types of commitment was not significant.

$<$ Insert Table 4 about here $>$ 
Table 4: Total effects

\begin{tabular}{lcccc}
\hline & $\begin{array}{c}\text { Change in CSR } \\
\text { behavior }\end{array}$ & AFFCOM & NORMCOM & CONTCOM \\
\hline CSR orientation & $0.280^{* * *}$ & $0.275^{* * *}$ & $0.285^{* * *}$ & $0.142 * * *$ \\
EXPE & $\mathrm{na}^{\mathrm{a}}$ & $0.046 \mathrm{~ns}$ & $0.048 \mathrm{~ns}$ & $0.024 \mathrm{~ns}$ \\
REWA & $\mathrm{na}^{\mathrm{a}}$ & $0.260^{* * *}$ & $0.269 * * *$ & $0.134^{* * *}$ \\
COER & $\mathrm{na}^{\mathrm{a}}$ & $-0.020 \mathrm{~ns}$ & $-0.020 \mathrm{~ns}$ & $-0.010 \mathrm{~ns}$ \\
\hline
\end{tabular}

Notes:

$* * * p \leq 0.01, * * p \leq 0.05$, ns - not significant

a not applicable - the total effects is the same as the direct effect (see Table 3)

\subsection{Mediation effects}

Mediation effects were assessed simultaneously. That is to say all the mediators were included in the analyses at the same time. We first assessed the requirements for mediation to take place by using the Baron and Kenny four step-approach, which showed for the first step that in the absence of the mediators expert power $\left(\mathrm{H}_{10 \mathrm{a}}\right)$, reward power $\left(\mathrm{H}_{10 \mathrm{~b}}\right)$ and coercive power $\left(\mathrm{H}_{10 \mathrm{c}}\right)$, CSRO has a significant effect on Change in SME behavior $(\beta=0.517, \mathrm{p}<0.01)$. Requirements for steps two, three, and four are met for expert power and reward power but not for coercive power. For step two, the results show (Table 3) that CSRO has a significant effect on expert power and reward power but not on coercive power. For step 3, the mediators should have a significant effect on the outcome construct. Again, this was the case for expert power and reward power but not for coercive power (Table 3). Finally, to meet the requirements for step four, the effect of CSRO to change in SME behavior should weaken in the presence of the mediators. This was the case when the mediators are simultaneously present (change in path coefficient -0.222). Taken together, these findings suggest that the effects of CSRO on change in CSR behavior are mediated by expert power and reward power and not by coercive power. To test the significance of the mediation and its strength, we used the recommended bootstrapping approach (Preacher \& Hayes, 2008), which is also argued to suit PLS-SEM and is superior to other tests such as the Baron and Kenny test or Sobel test (Hair et al., 2013, p.223). Bootstrapping was based on 5,000 bootstrap samples and the strength of the mediation was assessed with the Variance Accounted 
For (VAF) value. Table 5 illustrates the results of the mediation analysis by showing the indirect effects, total effects, and VAF. The results of the bootstrapping show that the indirect effect is not significant for the mediators, expert power and coercive power. Thus, only reward power mediates the effects of CSRO on change in SME behavior. The VAF value (0.362) shows partial mediation.

Table 5: Mediation analysis

\begin{tabular}{lccc}
\hline & Indirect effects & Total effects $^{\text {a }}$ & VAF \\
\hline CSR orientation $\rightarrow$ EXPE $\rightarrow$ Change in CSR behavior & $0.043 \mathrm{~ns}$ & $0.338^{* * *}$ & $\mathrm{n} / \mathrm{a}^{\mathrm{b}}$ \\
CSR orientation $\rightarrow$ REWA $\rightarrow$ Change in CSR behavior & $0.168^{* * *}$ & $0.463^{* * *}$ & 0.362 \\
CSR orientation $\rightarrow$ COER $\rightarrow$ Change in CSR behavior & $0.003 \mathrm{~ns}$ & $0.298^{* * *}$ & $\mathrm{n} / \mathrm{a}^{\mathrm{b}}$ \\
EXPE $\rightarrow$ Change in CSR behavior $\rightarrow$ AFFCOM & $0.031 \mathrm{~ns}$ & $0.170^{* * *}$ & $\mathrm{n} / \mathrm{a}^{\mathrm{b}}$ \\
EXPE $\rightarrow$ Change in CSR behavior $\rightarrow$ NORMCOM & $0.031 \mathrm{~ns}$ & $0.150^{* *}$ & $\mathrm{n} / \mathrm{a}^{\mathrm{b}}$ \\
EXPE $\rightarrow$ Change in CSR behavior $\rightarrow$ CONTCOM & $0.010 \mathrm{~ns}$ & $0.078 \mathrm{~ns}$ & $\mathrm{n} / \mathrm{a}^{\mathrm{b}}$ \\
$\mathrm{REWA} \rightarrow$ Change in CSR behavior $\rightarrow$ AFFCOM & $0.172^{* * *}$ & $0.400^{* * *}$ & 0.430 \\
$\mathrm{REWA} \rightarrow$ Change in CSR behavior $\rightarrow$ NORMCOM & $0.171^{* * *}$ & $0.432^{* * *}$ & 0.397 \\
$\mathrm{REWA} \rightarrow$ Change in CSR behavior $\rightarrow$ CONTCOM & $0.058 \mathrm{~ns}$ & $0.233^{* * *}$ & $\mathrm{n} / \mathrm{a}^{\mathrm{b}}$ \\
COER $\rightarrow$ Change in CSR behavior $\rightarrow$ AFFCOM & $-0.013 \mathrm{~ns}$ & $-0.083 \mathrm{~ns}$ & $\mathrm{n} / \mathrm{a}^{\mathrm{b}}$ \\
COER $\rightarrow$ Change in CSR behavior $\rightarrow$ NORMCOM & $-0.013 \mathrm{~ns}$ & $0.003 \mathrm{~ns}$ & $\mathrm{n} / \mathrm{a}$ \\
COER $\rightarrow$ Change in CSR behavior $\rightarrow$ CONTCOM & $-0.004 \mathrm{~ns}$ & $0.237^{* * *}$ & $\mathrm{n} / \mathrm{a}^{\mathrm{b}}$ \\
\hline CO & &
\end{tabular}

Notes:

$* * * \mathrm{p} \leq 0.01, * * \mathrm{p} \leq 0.05$, ns - not significant

a Total effects in the mediation model include the added direct paths (c) from X to $\mathrm{Y}$

b VAF not calculated as the indirect effect is not significant

\section{Findings}

Results indicate that large firms with a high degree of CSRO are more likely to exercise both expert power and reward power confirming $\mathrm{H}_{1}$ and $\mathrm{H}_{2}$. As hypothesized, firms with a high CSRO are also found to be less likely to exercise coercive power. However, while the direction of the effect is consistent with what we predicted, the effect is found to be non significant $(p<0.05)$. Furthermore, we hypothesize and find that the greater exercise of both expert power and reward power lead to a significant positive change in SME CSR behavior, confirming $\mathrm{H}_{4}$ and $\mathrm{H}_{5}$. In terms of the effect on the use of coercive power by large CSRO firms, while the direction of the relationship shows that greater use of coercive power will reduce CSR behavioral change 
by SMEs, the effect is non-significant $(p<0.05)$. As hypothesized, when SMEs are more likely to change their CSR behavior, it increases their level of commitment (of all three types) to their large partner confirming $\mathrm{H}_{8-10}$. Specifically, when the SMEs change their CSR behavior, that behavioral change itself increases their affective, normative as well as continuance commitment towards their large partner firm. The effect is found to be smallest on continuance commitment, relative to the effects on affective and normative commitment.

In testing the meditating effects of power, firstly, the data shows that CSRO of the large firm has a positive influence on change in SME CSR behavior. Data also shows a significant meditating effect of reward power, confirming $\mathrm{H}_{7 \mathrm{~b}}$. Expert power, the other type of positive power investigated, does not mediate the relationship between CSRO of large firm and change in SME CSR behavior. While we hypothesized a significant mediating effect for coercive power, consistent with the non-significant direct effects associated with coercive power discussed above, we do not find evidence for a significant mediating effect. Thus, we do not find support for $\mathrm{H}_{7 a}$ and $\mathrm{h}_{7 \mathrm{c}}$.

For control purposes, we also accounted for the effects of a) relationship duration between the SME and the large partner, b) the shared values between the two firms, c) turnover of the SME, and d) the number of employees working for the SME. None of the effects of the controls on change in CSR behavior were found to be significant indicating that the results were not sensitive to the inclusion of these variables. In terms of commitment and the controls, we confirm that relationship duration and commitment is positively related, illustrating the robustness of the results. Finally, we find that turnover is positively related to affective commitment and that number of employees is negatively associated with normative commitment.

\section{Discussion and conclusions}

\subsection{Effects of CSR orientation of large firms on the exercise of power}


Large firms with a high degree of perceived CSRO are more likely to exercise both expert power and reward power, with the latter taking a prominence. This was underpinned by a belief that a firm positioned as CSR oriented will reflect this in its stakeholder treatment (Peloza \& Shang, 2011). First, our findings are in line with Stakeholder theory which requires that the dominant firm, through collaboration, facilitates knowledge transfer to build partners' CSR capacity and capability (Freeman \& Liedtka, 1997; Myllykangas, Kujala, \& Lehtimäki, 2012). Second, and in line with Carrol's (1979) view of CSR, the large firm must succeed economically to be able to fulfil its ethical and discretionary obligations. The use of reward power demonstrates the dominant partner's willingness to share wealth (Blombäck \& Wigren, 2008), but also acts as a means to motivate SME behavioral change. Our findings suggest that creating the conditions and climate to facilitate change is more pressing for the dominant firm than rewarding their trading partners. We also find that the effect of CSRO on the use of coercive power is not significant, although the direction itself is as predicted. This means that CSR oriented firms are not necessarily less likely to use negative power to effect SMEs behavioral change. It is noteworthy that the conditions which gave the dominant partner power over the SME do not dissipate because of adopting a CSR business perspective. Instead CSRO acts as a restraining force, so despite their ability to use coercive power to gain SME compliance, the large firm chooses not to, thus resulting in an overall neutral effect. In this research we add to the insights provided by Tang and Tang (2012) that stakeholder CSRO impacts the CSR activities of an SME. We do this by taking a different and more focused perspective i.e. we specifically focused on the large firm and their SME partner, to examine the effect of positive and of negative power used.

\subsection{Effects of exercise of power by large firms on CSR behavioral change by SMEs}

The findings support that application of both expert power and reward power lead to a significant positive change in SME CSR behavior. Reward power has a greater influence in 
changing SME CSR behavior than expert power. SMEs, whilst wanting to fulfil social and environmental obligations, have to focus first and foremost on the business case (i.e. will they be able to bear the extra costs incurred in changing their CSR behavior measured against likely income generated) (Jenkins, 2006; Worthington, Ram, \& Jones, 2006). This accentuates the importance of gaining reward from effort. Though the SMEs have still to learn how to comply with their dominant partner's CSR requirements (cost of doing business), knowing the commercial benefits to be gained from this seems to be a more powerful change motivator. However, the relationship between coercive power and SME CSR behavioral change is essentially neutral (i.e. it does not prevent or support change from taking place). This suggests that the relationship is influenced by, for example, the state of the relationship between the parties (Leonidou et al., 2008), and whether the SME is unable to change because of constrained resources or lack of willingness of the owner manager, who expresses dissatisfaction for the way they are treated through non-compliance (Haberberg et al., 2010).

\subsection{Effects of CSR behavioral change by SMEs on their commitment to the large partner}

CSR behavior change increased the SMEs commitment towards the large partner firm. Thus, where there is mutual agreement of the benefits of CSR (Peloza \& Shang, 2011) and resultant change on the part of the SME, it naturally increases the positive dimensions of commitment, especially, affective commitment. This is comparable to Meyer et al.,'s (2002) findings in a different context. The effect is less on continuance commitment. This is probably not surprising given that continuance commitment is a negative type of commitment, one driven by being forced into or entrapped in a relationship vis-à-vis the other two types of commitment (Withey \& Cooper, 1989). This indicates that the commercial imperative for SMEs forms their primary driver for working with the larger partner. This has two dimensions, first the "cost" of the change process for the SME means that they have to stay in the partnership long enough to 
get payback. Second, having borne the cost of change to fit the requirements of an existing partner, exiting the relationship may force them to go through the process again to suit the needs of a new dominant firm. So by forcing the SME to comply the dominant firm in effect entraps that organization, which clearly is contra to the core principles of CSR and stakeholder theory, indicating that a toxic relationship between the parties will exist harming the ability to support CSR development.

\subsection{Mediating effects}

The CSRO of the large firm is influenced by the degree of reward power exercised by the large partner, but not expert or coercive power. While large partner CSRO can lead to a change in SMEs CSR behavior the way the large partner uses power has a significant impact on the change in SME CSR behavior. The positive use of power through rewards to help the SMEs plays an important and critical role in influencing the desired behavior by the SMEs. While it is found that large CSR oriented firms are not more likely to use rewards, from the SMEs point of view, their appeal is apparent. This means that the behavioral change is driven because of the rewards and not necessarily due to mere association with a CSR oriented partner. While expertise on its own has a direct impact, expert power is not a significant mediation, suggesting that it is not a substitute for the CSRO of the large firm. In this we provide the change mechanism lacking in the Perrini, Russo and Tencati (2007) study as to how the large partner should deepen CSR commitment and activity of partnering SMEs.

\subsection{General Discussion}

This study, by taking a CSR perspective, has thrown new light on the role power plays in influencing the relationship between a large firm and its trading partners. Our starting point was that power has always played a significant role in influencing how one organization works with another to achieve its aims. For large firms there is strong anecdotal evidence that to protect their 
investment in CSR, they use coercive power to gain the compliance of their SME trading partners. Stakeholder theory sets out the overarching principles of how the dominant partner should interact with others, and indicates that power should be used benevolently to encourage and support a change process. The large firm's imperative of having to be seen as acting to further CSR, and the different levels of CSR commitment by their trading partners, may mean that the temptation to use coercive power will be overwhelming. Our findings raise considerable questions about the wisdom of using coercive power to achieve CSR alignment.

We also examined the relationship between the level of perceived CSRO of the large firm and the power 'form' used. Perceived CSRO was used because it is how the SME viewed their dominant partner which forms expectations of their treatment within the relationship. We argued that a CSR orientated firm would use power positively to achieve their aims. What we found is that large CSR orientated firms are more likely to use expert power than reward power. But, SMEs react better to reward power than to expert power reflecting their business imperatives and realities. Whilst as highlighted the SME needs to understand how to act in a socially and environmentally acceptable manner, the dominant partner should lead with the business case benefits in their promotion of the need for change. We find that the direct effect of CSRO on use of coercive power is non-significant, indicating a neutral effect, despite strong anecdotal evidence of the use of coercive power among large firms. In the context of CSR, we believe that this reflects the result of a set of competing forces. On one hand large organizations have innate power and thus, an inherent tendency to use it in a coercive way. On the other hand, they also have external expectations, especially as CSR oriented firms, to behave as good corporate citizens, and thus limit displays of overt negative power. The neutral effect is likely to be an outcome of these forces. 
The perceived CSRO of the firm led the SME to expect the deployment of positive power in the relationship with the dominant partner. We examined this in the context of which power form would more likely affect change in the SME CSR behavior. The relationship between reward and SME behavioral change, and expert and SME behavioral change was positive. Reward power was seen as a stronger motivator for change. This is a plausible outcome; after all, SMEs income from working with their dominant partner has to be sufficient for their commercial success. The fact that we have a reversal in the influence between these two power types when looked at as expectation of power used, compared to as a driver of change, is interesting. The logic in this is likely to do with the business realities faced by SMEs. They know that to work with a dominant partner they have to learn how to (expert), but to make the changes, the reward for their endeavors must be sufficient. The use of coercive power seems to be counterproductive. Its application perhaps indicates the near end of the relationship or the lack of sincerity of the large firms CSR efforts. In this sense coercive power creates a toxic environment between the firms, creating a poor environment for collaborative activity to take place. This led us to consider the third relationship of how different forms of power influenced SME commitment. A positive relationship was found between SME CSR behavioral change and commitment. This was stronger for affective (positive dimension of commitment) than for normative (neutral), and continuance (negative) form of commitment, which is akin to entrapping the SME in the relationship. For the large firm this result suggests that the effort expended in gaining CSR behavioral change will lead to an overall strengthening of the relationship by creating the conditions that support their own evolution and embedding of CSR. This is seen as important to deepen their commitment to, and capability in, CSR (Cramer et al., 2004; Porter \& Kramer, 2006). Positive change and strengthening of the bond are most likely achieved through co-operation than through coercion. 
The study has identified a number of ways in which three types of power, expert \& reward (positive) and coercive (negative), influence the relationship between a dominant firm and its trading partners with regard to CSR alignment. First, power is an instrument for affecting change. If used coercively the impact on the relationship seemingly is neutral, although, at a perceptual level the SME's view of the dominant partner will be damaged. So they will try to comply with the wishes of the dominant partner, but will see the use of coercive power as an indicator that the foundation underpinning their business relationship is less secure. This will reduce their desire to change. The outcome when these two forces combine is neutral (i.e. no CSR behavioral change). Second, when a firm promotes itself as CSR orientated it creates expectations for its trading partners that they will be supported to change their CSR behavior.

However, coercive power if used by a firm promoting it-self as CSR orientated would strongly indicate that its activities are marketing rhetoric, not real. This would suggest that the firm in its business model was more aligned with shareholder theory, i.e., securing corporate success is its paramount concern, rather than working within the expectations of the stakeholder theory. Linking these two perspectives is the corporate needs of large firms, i.e. to be seen to act ethically, socially and environmentally, to protect the reputation and ensure profit, which compels them to use negative power. To use negative power signals to other firms and to their own SME partners that they are perhaps insincere in their CSR, in turn reducing other firm's commitment to CSR. It may also indicate that such firms are still at relatively early stages of actually becoming CSR orientated.

Further, large firms that regularly use coercion may find it compelling to use coercive power to achieve change in their SME partner. This may be driven by a perception that the use of the 'stick' is the quickest way to achieve aims. Indeed, there may be circumstances under which coercion will work to achieve speedy change. We can speculate that where the SME is already 
committed to the large organization, especially in the form of continuance commitment characterised by entrapment of the former, coercive power can play a different role. Our model does not exclude this possibility. However, the findings suggest that the use of positive power by large firms strongly leads to effective CSR behavioural change on the part of the SME. These results convey a cautionary note to those firms who have an inherent tendency to use the 'stick' approach. Our findings suggest that the use of positive power by large firms strongly leads to effective CSR behavioural change on the part of the SME. These results convey a cautionary note to those firms who have an inherent tendency to use the 'stick' approach. However, large firms that regularly use coercion may find it compelling to use coercive power to achieve change in their SME partner. This may be driven by a perception that the use of the 'stick' is the quickest way to achieve aims. Indeed, there may be circumstances under which coercion will work to achieve speedy change. Where the SME is already committed to the large organization, especially in the form of continuance commitment characterised by entrapment of the former, coercive power may play a different role. Our model does not exclude this possibility. We can therefore speculate that a possible paradox can exist (Lewis 2000), because the use of coercive and non-coercive power can both lead to the same outcome of better CSR alignment between firms. If the outcome is the same regardless of the approach taken (coercive vs non-coercive) this may suggest that what connects them needs more thought. Taking a Yin Yang perspective as suggested by Fang (2011) may capture the dynamic interplay between these forces and thus offer holistic insight into the change journey.

A number of management implications stem from this. For large firms, following a CSR agenda, gaining 'buy in' from their trading partners is foundational to success. How they do this through the application of power can lay the foundation for building a trading network where actors are motivated and able to evolve their own CSR capabilities and where congruency of 
action is gained. Or it can serve to create a climate where a partner's compliance is bound by commercial necessity not genuine willingness to change, resulting in relationship breakdown. Despite compelling reasons to force change by using coercive power, we argue, based on our findings, that this will lay the foundation for failure. If used, it should be done, with full understanding of the damage it may cause to their reputation and the potential for SMEs unwillingness to form a business relationship. By pursuing a CSR agenda, large firms commit to working with their trading partners to achieve social and environmental aims. Working in a positive way through use of reward and expert power, increases their overall attractiveness to firms that share such ambitions. This lays stronger foundations for the development of longer term relationships and positive forms of commitment which support the development of the large firm CSRO. For the SME, being able to trust the sincerity of the large firm's CSRO allows them to judge more easily whether to chose to work with that organization. What is important is their ability to learn about what CSR means for the dominant firm, how they can comply with the partner's expectations and, their own ability to succeed. Power when used as a positive force in this context reinforces CSR and stakeholder theory as a force for good.

\section{Direction for future research and research limitations}

The current research, while answering some key questions, also raises areas for further research. In this study we examined the SMEs perception about the CSR orientation of their larger firm partners, yet this might not wholly reflect the true nature of the large firms CSR activity or indeed their sincerity and as such is a limitation of the study. As such we have not assessed whether the large partner was objectively CSR oriented. The rationale for doing so was that behaviors are often driven by perceptions, and moreover, we have followed prior research on this topic in doing so. Furthermore, it is difficult to unequivocally identify an ideal CSR oriented firm. Somewhat similar to reputation, it is at least partly about how others see the firm. Also, the 
premise behind this study is that large firms will be the dominant and therefore a more powerful partner in a SME relationship. We accept that power can be based on determinants other than firm size, and that the SME may hold power over the large firm through resource scarcity, patents, proximity etc. How this might impact the adoption of CSR remains unknown but its examination would provide different insights into how CSR alignment is achieved and whether it reflects more the view of the SME or the large firm. How CSRO can be identified and evaluated is challenging. The way an organization deploys power to affect change can be used to measure the level of CSRO. The study showed that when a firm is considered to be strongly CSR orientated, the expectation was that it would use power positively. If instead it relied on coercive forms it would suggest that its overall level of orientation was low or even superficial. Therefore, an interesting question is whether the type of power deployed can be used to measure the sincerity of a firm's CSR activities and thus actual depth of orientation. Whilst we note that power type influences SME CSR behavioral change, we are uncertain whether this is tactical or strategic. This matters as the latter would imply that the SME has deeply embraced CSR into its business model, reinforcing their willingness to commit to a long term relationship, a tactical changeless so. Whilst this study provides strong evidence of how different types of power can influence change processes within partner organizations, the relationships tested are linear. Although the rationale for examining linear relationships is well understood, linear models do not fully capture the complexity of social systems. Alternative methodologies can therefore complement research in this domain. For instance, qualitative research would allow different and complementary knowledge to be gained. Here, we draw specific reference to the work of Lewis (2000) which discussed the concept of paradox and that of Fang (2011) suggesting that an alternative lens such as the Yin Yang perspective can help expose the dynamic inter-relationships that exist between firms. Through such enquiry future research can examine the tensions suggested in this study further; specifically, how inter-firm relationships are moulded by complex 
and dynamic forces shaped by the interactions of human actors in what are unique business cultures. Finally, investigating the true causal effects of power on SME CSR commitment requires a longitudinal approach, utilizing data over a period of time. Such an approach will increase our understanding of the causal relationships amongst the constructs studied here. 


\section{References}

Adobar, H. (2011). Alliances as collaborative regimes: An institutional based explanation of interfirm collaboration. Competitiveness Review: An International Business Journal, 21(1), 66-88.

Allen, N. J., and Meyer, J. P. (1990). The measurement and antecedents of affective, continuance, and normative commitment to the organization. Journal of Occupational Psychology, 63, $1-18$.

Amaeshi, K., Adi, A. B. C., Ogbechie, C., \& Amao, O. O. (2006). Corporate social responsibility in Nigeria: western mimicry or indigenous influences? Journal of Corporate Citizenship, 24, 83-99.

Armstrong, J. S,. \& Overton, T. S. (1977). Estimating nonresponse bias in mail surveys. Journal of Marketing Research, 16(August), 396-402.

Aulakh, P. S., \& Gencturk, E. F. (2000), International Principal-Agent Relationships: Control, Governance and Performance, Industrial Marketing Management, 29(6), 521-538.

Bansal, H. S., Irving, P. G., \& Taylor, S. F. (2004). A three-component model of customer to service providers. Journal of the Academy of Marketing Science, 32(3), 234-250.

Barabel, M., \& Meier, O. (2012). How profound changes in stakeholder relations allowed an SME to enter and gain a foothold in a highly competitive sector? International Business Research, 5(7), 84-96.

Benson, P.G., Dickinson, T.L., \& Neidt, C.O. (1987). The relationship between organizational size and turnover: a longitudinal investigation, Human Relations, 40(1), 15-29.

Bertels, S., \& Peloza, J. (2011). Running just to stand still? Managing CSR reputation in an era of ratcheting expectations. Corporate Reputation Review, 11(1), 56-72.

Bigné, J.E., Blesa, A., Küster, I., \& Andreu, L. (2002). Market orientation: An antecedent to the industrial manufacturer's power. European Journal of Marketing, 38(1/2), 175-193.

Blois, K., \& Hopkinson, G. C. (2013). The use and abuse of French and Raven in the channels literature, Journal of Marketing Management, 29(9-10), 1143-1162. 
Blombäck, A., \& Wigren, C. (2008). Challenging the importance of size as determinant for CSR activities. Management of Environmental Quality: An International Journal, 20(3), 255270.

Blowfield, M., \& Murray, A. (2011.) Corporate responsibility (2nd ed.). Oxford: Oxford University Press.

Boulding, K. E. (1989). Three faces of power. Newbury Park: Sage Publications.

Cambra-Fierro, J., Hart, S., \& Polo-Redondo, Y. (2008). Environmental respect: Ethics or simply business? A study in the small and medium enterprise (SME) context. Journal of Business Ethics, 82, 645-656.

Campopiano, G., \& De Massis, A. (2015). Corporate social responsibility reporting: a content analysis in family and non-family firms. Journal of Business Ethics, 129(3), 511-534.

Carroll, A. B. (1979). A three dimensional conceptual model of corporate social performance. Academy of Management Review, 4(4), 497-505.

Carroll, A. B. (1999). Corporate social responsibility. Evolutional of a definitional constructs. Business and Society, 38(3), 268-295.

Carter, C. R., \& Jennings, M. M. (2004). The role of purchasing in corporate social responsibility: a structural equation analysis. Journal of Business Logistics, 25(1), 145186.

Castka, P. M., Balzarova, C., Bamber \& Sharp, J. (2004). How can SMEs effectively implement the CSR agenda? A UK case study perspective. Corporate Social Responsibility, 11(3), 140-149.

Chin, W. W. (1998). The partial least squares approach to structural equation modeling. In Modern methods in business research, Marcoulides GA (ed). New Jersey: Lawrence Erlbaum Associates.

Coser, L. (1956). The functions of social conflict. New York: Free Press.

Cramer, J., Jonker, J., \& Van der Heijden, A. (2004). Making sense of Corporate Social Responsibility. Journal of Business Ethics, 55, 215-222.

Crane, A. (2001). Unpacking the ethical product. Journal of Business Ethics, 30, 361-373. 
Doppelt, B. (2003). Leading change toward sustainability, a change management guide for business, government and civil society. Sheffield, UK: Greenleaf Publishing.

Dunphy, D. C., Griffiths, A., \& Benn, S. (2003). Organizational change for corporate sustainability: a guide for leaders and change agents of the future. London: Routledge.

Fang, T. (2011), Yin Tang: A new perspective on culture. Management and Organization Review, 8(1), 25-50.

Fernandez-Feijoo, B., Romero, S., \& Ruiz, S. J. (2014). Effect of Stakeholders' Pressure on Transparency of Sustainability Reports within the GRI Framework. Journal of Business Ethics, 122(1), 53-63.

Fornell, C., \& Bookstein, F. L. (1982). Two structural equation models: LISREL and PLS applied to consumer exit-voice theory. Journal of Marketing Research, 19(4), 440452.

Fornell, C., \& Larcker, D. F. (1981). Evaluating structural equation models with unobservable variables and measurement error. Journal of Marketing Research, 18, 39-50.

Freeman, E. (1984). Strategic management: A stakeholder approach. Boston, MA: Pitman.

Freeman, E. (1994). The politics of stakeholder theory: some future directions. Business Ethics Quarterly, 4(4), 409-421.

Freeman, R. E., \& Liedtka, J. (1997). Stakeholder capitalism and the value chain. European Management Journal, 15(3), 286-296.

Frooman, J. (1999). Stakeholder influences strategies. Academy of Management Review, 24(2), 191-205.

Gaspar, R.E. (2017) Large firm dominance on country's entrepreneurship potentials, Journal of Global Entrepreneurship Research, 7(1), 1-16.

Granovetter, M. (2005). The impact of social structure on economic outcomes. The Journal of Economic Perspectives, 19(1), 33-50. 
Guthrie, J., Petty, R., \& Ricceri. F. (2006). The voluntary reporting of intellectual capital. Comparing evidence from Hong Kong and Australia. Journal of Intellectual Capital, 7(2), 254-271.

Haberberg, A., Gander, J., Rieple, A., Helm, C., \& Martin-Castilla, J.I. (2010). Institutionalizing idealism: the adoption of CSR practices. Journal of Global Responsibility, 1(2), 366-381.

Hair J. F. Jr., Sarstedt, M., Piepen, T. M., \& Ringle, C. M. (2012). The use of partial least squares structural equation modeling in strategic management research: A review of past practices and recommendations for future applications. Long Range Planning, 45(5-6), 320-340.

Hair, J. F. Jr., Hult, G. T. M., Ringle, C. M., \& Sarstedt, M. (2013). A primer on partial least squares structural equation modeling (PLS-SEM). Los Angeles: Sage.

Harman, H. H. (1967). Modern factor analysis (2nd ed.). Chicago: University of Chicago Press.

Heath, J. (2006). Business ethics without stakeholders. Business Ethics Quarterly, 16(4), 533557.

Henderson, D. (2001). Misguided virtue: False notions of Corporate Social Responsibility. London: The Institute of Economic Affairs.

Hennig-Thurau, T., Henning, V., Sattler, H. (2007). Consumer file sharing of motion pictures. Journal of Marketing, 71, 1-18.

Henseler, J., \& Chin, W. W. (2010). A comparison of approaches for the analysis of interaction effects between latent variables using partial least squares path modelling. Structural Equation Modeling, 17(1), 82-109.

Hietbrink, J. J. C., Berens, G., \& van Rekom, J. (2010). Corporate social responsibility in a business purchasing context: the role of CSR type and supplier product share size. Corporate Reputation Review, 13(4), 284-300.

Homburg, C., Stierl, M., \& Bornemann, T. (2013). Customer outcomes of corporate social responsibility in supplier-customer relationships. Marketing Science Institute Working Paper Series, Report No. 13, 13-119.

Jenkins, J. (2009). A business opportunity model of corporate social responsibility for small and medium-sized enterprises, Business Ethics: a European Review, 18(1), 21-36 
Jenkins, J. (2006). Small business champions for corporate social responsibility. Journal of Business Ethics, 67, 241-256.

Kim, S., \& Park, H. (2013). Effects of various characteristics of social commerce (s-commerce) on consumers' trust and trust performance. International Journal of Information Management, 33(2), 318-332.

Kotonen, U. (2009). Formal corporate social responsibility reporting in Finnish listed companies. Journal of Applied Accounting Research. 10(3), 176-207.

Larson, P. D. (2005). A note on mail surveys and response rates in logistics research, Journal of Business Logistics, 26(2), 211-222.

Lauda, T. (2011). Drivers and barriers of CSR and the size and internationalization of firms. Social Responsibility Journal, 7(2), 234-256.

Lederhaus, M. A. (1984). Improving marketing channel control through power and exchange. Journal of the Academy of Marketing Science, 12(3), 18-34.

Lewis, M.W. (2000). Exploring paradox: Toward a more comprehensive guide. Academy of Management Review, 25 (4), 760-776.

Leonidou, C. L., Talis, M.A., \& Leonidou, C.N. (2008). Exercised power as a driver of trust and commitment in cross-border industrial buyer-seller relationships. Industrial Marketing Management, 37, 92-103.

Liang, H., Saraf, N., Hu, Q., \& Xue, Y. (2007). Assimilation of enterprise system: The effect of institutional pressures and the mediating role of top management. MIS Quarterly, 31(1), 59-87.

Lindgreen A., Swaen V., Harness D., \& Hoffmann M. (2012). The role of 'High Potentials' in integrating and implementing corporate social responsibility. Journal of Business Ethics, 99(1), 73-91.

Lindgreen, A., Swaen, V., \& Johnston, W. J. (2009). Corporate social responsibility: an empirical investigation of U.S. organizations. Journal of Business Ethics, 85, 303-323.

Maignan, I., \& Ferrell, O.C. (2000). Measuring corporate citizenship in two countries: The case of the United States and France. Journal of Business Ethics, 23, 283-297. 
Marin, L., Ruiz, S. \& Rubio, A. (2009) The role of identity salience in the effects of corporate social responsibility on consumer behavior. Journal of Business Ethics, 84(1), 65-78.

McWilliams, A., Siegal, D.S., \& Wright, P. M. (2006). Corporate social responsibility: strategic implications. Journal of Management Studies, 43(1), 1-18.

Meyer, J. P., \& Allen, N. J. (1984). Testing the "side-bet theory” of organizational commitment: some methodological considerations. Journal of Applied Psychology, 69, 372-378.

Meyer, J. P., \& Allen, N. J. (1991). A three-component conceptualization of organizational commitment. Human Resource Management Review, 1, 61-89.

Meyer, J. P., \& Allen, N. J. (1997), Commitment in the workplace: Theory, research, and application. Thousand Oaks, CA: Sage.

Meyer, J. P., Stanley, D.J., Herscovitch, L., \& Topolnytsky, L. (2002). Affective, continuance, and normative commitment to the organization: A meta-analysis of antecedents, correlates, and consequences. Journal of Vocational Business, 61, 20-52.

Mohr, L. A. \& Webb, D. J. (2005). The effects of corporate social responsibility and prices on consumer response. The journal of Consumer Affairs, 39(1), 121-147.

Morgan, R. M., \& Hunt, S. D. (1994). The commitment-trust theory of relationship marketing, Journal of Marketing, 58(3), 20-38.

Morhardt, J. E. (2010). Corporate social responsibility and sustainability reporting on the internet. Business Strategy and the Environment, 19, 436-452.

Mullen, M. R. (1995). Diagnosing measurement equivalence in cross-national research. Journal of International Business Studies, 26(3), 573-596.

Murillo, D., \& Lozano, J. M. (2006). SMEs and CSR: an approach to CSR in their own words. Journal of Business Ethics, 67, 227-240.

Myllykangas, P., Kujala, J., \& Lehtimäki, H. (2012). Analyzing the essence of stakeholder relationships: what do we need in addition to power, legitimacy, and urgency? Journal of Business Ethics, 96, 65-72.

Nunnally J. C., \& Bernstein, I. H. (1994). Psychological theory. New York: McGraw-Hill. 
Panapanaan, V. M., Linnanen, L., Karvonen, M-M., \& Phan, V. T. (2003). Roadmapping corporate social responsibility in Finnish companies. Journal of Business Ethics, 44, 133148.

Peloza, J., \& Shang, J. (2011). How can corporate social responsibility activities create value for stakeholders? A systematic review. Journal of the Academy of Marketing Science, 39(1), 117-135.

Perrini, F., Russo, A. \& Tencati, A. (2007). CSR strategies of SMEs and Large Firms. Evidence from Italy. Journal of Business Ethics, 74, 285-300.

Phillips, P. A., (2003). Customer-oriented hotel aesthetics: A shareholder value perspective.

Journal of Retail and Leisure Property. 3(4), 365-373.

Podsakoff, P. M., MacKenzie, S. B., Lee, J.-Y., \& Podsakoff, N. P. (2003). Common method biases in behavioral research: A critical review of the literature and recommended remedies. Journal of Applied Psychology, 88(5), 879-903.

Porter, M.E., \& Kramer, M.R. (2006). Strategy and society: the link between competitive advantage and corporate social responsibility. Harvard Business Review, 84(12), 78-92.

Preacher, K. J., \& Hayes, A. F. (2008). Asymptotic and resampling strategies for assessing and comparing indirect effects in multiple mediator models. Behavior Research Methods, 40(3), 879-891.

Preuss, L., \& Perschke, J. (2009). Slipstreaming the larger boats: social responsibility in medium-sized businesses. Journal of Business Ethics, 92, 631-551.

Rajaguru, R., \& Matanda, M. J. (2011). Role of inter-organizational compatibility and IOIS integration in large firms and SMEs retailing chains. Asia Pacific Journal of Marketing and Logistics, 23(2), 177-199.

Raven, B., \& French, J. R. P. Jr. (1958). Legitimate power, coercive power, and observability in social influence. Sociometry, 21(2), 83-97.

Ringle, C. Wende, S. \& Will, A. (2005). Smart-PLS version 2.0, Retrieved from http://www.smartpls.de.

Russo, A., \& Perrini, F. (2009). Investing stakeholder theory and social capital: CSR in large firms and SEMs. Journal of Business Ethics, 91, 207-221. 
Sahadev, S. (2005). Exploring the role of expert power in channel management: An empirical study. Industrial Marketing Management, 34, 487-494.

Sethi, P. S., Veral, A. E., Shapiro, J. H., \& Emelianova, O. (2010). Mattel, Inc.: global manufacturing principles (GMP) - a life-cycle analysis of a company based code of conduct in the toy industry. Journal of Business Ethics, 99, 483-517.

Shum, P. K., \& Yam, S. L. (2010). Ethics and law: guiding the invisible hand to correct corporate social; responsibility externalities. Journal of Business Ethics, 98, 549-571.

Sims, R. R. (2003). Ethics and Corporate Social Responsibility: Why giants fall. Westport, CT: Greenwood Publishing Group.

Smith, J.H (2003). The shareholder vs. stakeholder debate. MIT Sloan Managmenet Review, 44, 85-90.

Spence, L. J., \& Rutherford, R. (2003). Small business and empirical; perspectives in business ethics: editorial Journal of Business Ethics, 92, 631-551.

Tang, Z., \& Tang, J. (2012). Stakeholder-firm power difference, stakeholders’ CSR orientation, and SMEs' environmental performance in China. Journal of Business Venturing, 27, 436455.

Theyel, G., \& Hofman, K. (2012). Stakeholder relations and sustainability practices of US small and medium-sized manufacturers. Management Research Review, 35(12), 1110-1133.

Thorne, D. M., Ferrell, O. C., \& Ferrell, L. (2008). Business and society: A strategic approach to social responsibility (3rd ed.). Boston: Houghton Mifflin Company.

Turker, D. (2009). Measuring corporate social responsibility: A scale development study. Journal of Business Ethics, 85, 411-427.

Van Marrewiki, M., \& Were, M. (2003). Multiple levels of corporate sustainability. Journal of Business Ethics, 44(2/3), 107-119.

Van Tulder, R., \& van der Zwart, A. (2006) International business-society management: Linking corporate responsibility and globalization. London: Routledge.

Vianova, M., Lozano, J. M., \& Arenas, D. (2008). Exploring the nature of the relationship between CSR and competitiveness. Journal of Business Ethics, 87, 57-69. 
Weyzig, F. (2009). Political and economic arguments for corporate social responsibility: Analysis and a proposition regarding the CSR agenda. Journal of Business Ethics, 86(4), 417-428.

Withey, M., \& Cooper, W. (1989). Predicting exit, voice, loyalty, and neglect. Administrative Science Quarterly, 34, 521-539.

Worthington, I., Ram, M., \& Jones, T. (2006). Exploring corporate social responsibility in the U.K. Asian small business community. Journal of Business Ethics, 67, 201-217.

Yuan, W., Bao, Y., \& Verbeke, A. (2011). Integrating CSR initiatives in Business: An organizing framework. Journal of Business Ethics, 101(1), 75-92.

Yung, Y. F., \& Bentler, P. M. (1996). Bootstrapping techniques in analysis of mean and covariance structures. In G.A. Marcoulides, R.E. Schumacker (Eds.), Advanced structural equation modelling: Issues and techniques, Erlbaum, Mahwah, pp. 195-226.

Zhuang, G., Xi, Y., \& Tsang, A. S. (2010). Power, conflict, and cooperation: the impact of Guanxi in Chinese marketing channels. Industrial Marketing Management, 39(1), 137149. 
(c) 2018. This manuscript version is made available under the CC-BY-NC-ND 4.0 license http:// creativecommons.org/licenses/by-nc-nd/4.0/ 52 


\section{Appendix}

Table 6 Scale items for construct measures

CSR orientation (based on Turker 2009)

\begin{tabular}{cc}
$\begin{array}{c}\text { Outer weights (Outer } \\
\text { Loadings) }\end{array}$ & $\begin{array}{c}\text { Factor } \\
\text { loadings }\end{array}$ \\
\hline $0.144 \mathrm{~ns}$ & \\
$0.779^{* * *}$ & \\
$0.565^{* * *}$ \\
$(0.897 * * *)$ \\
\hline $0.331^{* * *}$ \\
$\left(0.766^{* * *}\right)$ \\
\hline $0.305^{* * *}$ \\
$\left(0.784^{* * *}\right)$ \\
\hline $0.108 \mathrm{~ns}$ \\
\hline $0.790^{* * *}$ \\
$\left(0.918^{* * *}\right)$ \\
\hline $0.416^{* * *}$ \\
$\left(0.660^{* * *}\right)$ \\
\hline $0.439^{* * *}$ \\
$0.905^{* * *}$ \\
\hline $0.364 * * *$ \\
$\left(0.831^{* * *}\right)$ \\
\hline $0.140 \mathrm{~ns}$ \\
$\left(0.713^{* * *}\right)$ \\
\hline $0.351^{* * *}$ \\
$\left(0.843^{* * *}\right)$ \\
\hline $0.380^{* * *}$ \\
$\left(0.794^{* * *}\right)$ \\
\hline $0.441^{* * *}$ \\
$0.919^{* * *}$ \\
\hline $0.498^{* * *}$ \\
$\left(0.829^{* * *}\right)$ \\
\hline $0.348^{* * *}$ \\
$\left(0.766^{* *}\right)$ \\
\hline $0.414^{* * *}$ \\
$\left(0.778^{* * *}\right)$ \\
\\
\end{tabular}

Management beliefs - Organizational DNA

$0.144 \mathrm{n}$

The company always supports employee development.

$0.565^{* * *}$

The company always implements flexible policies to provide a good work \&

life balance for employees.

The company always considers the impact of managerial decisions on employees.

Acceptance of CSR as a business model

The company always emphasizes the importance of its social responsibilities to the society.

The company always encourages its employees to participate in voluntarily activities.

Economic - Legal dimensions

The company always respects consumer rights beyond the legal requirements.

The company always pays its taxes on a regular and continuing basis.

The company always complies with legal regulations completely and promptly.

The company always provides full and accurate information about its products to its customers.

Discretionary - Philanthropic dimensions

The company always invests to create a better life for future generations.

We attach great value to the technical knowledge that our partner provides to

We are very confident of the ability of our partner to give us technical guidance.

Reward Power (based on Bigne et al. 2004)

Our partner rewards us in some way when we do things the way they want.

Satisfying the wishes of our partner has a positive effect on our profits.

We believe that following the suggestions of our partner will benefit us on

0.847

other occasions.

Coercive Power (based on Leonidou et al. 2008)

Failing to comply with the requests of our partner will result in financial and

other penalties against our company.

Our partner will probably threaten to take some action if we do not comply

with their requests.

Our partner will probably withhold important support for our firm, if we did not show compliance with their demands. 


\begin{tabular}{|c|c|c|}
\hline \multicolumn{3}{|l|}{ Change in CSR behavior (based on Lindgreen et al. 2009) } \\
\hline Profitability, image and relations with stakeholders, employees and customers & $\begin{array}{l}0.805^{* * *} \\
0.981^{* * *}\end{array}$ & \\
\hline Improved relations with customers. & $\begin{array}{c}0.004 \mathrm{~ns} \\
\left(0.734^{* * *}\right)\end{array}$ & \\
\hline Improved relations with employees. & $\begin{array}{c}0.427^{* * *} \\
\left(0.821^{* * *}\right)\end{array}$ & \\
\hline Improved stakeholder relations in general. & $\begin{array}{l}0.320^{* * *} \\
\left(0.792^{* * *}\right)\end{array}$ & \\
\hline Attained desired profitability. & $\begin{array}{c}0.181 \mathrm{~ns} \\
\left(0.745^{* * *}\right)\end{array}$ & \\
\hline Improved corporate image/reputation. & $\begin{array}{c}0.301 \\
\left(0.856^{* * *}\right)\end{array}$ & \\
\hline Relations with local community & $\begin{array}{l}0.167 \mathrm{~ns} \\
0.774 * * *\end{array}$ & \\
\hline Improved relations with local community. & $\begin{array}{r}0.544^{* * *} \\
\left(0.962^{* * *}\right)\end{array}$ & \\
\hline Improved social health of local community. & $\begin{array}{c}0.259 \mathrm{~ns} \\
(0.909 * * *)\end{array}$ & \\
\hline Improved economic health of local community & $\begin{array}{c}0.290^{* * *} \\
\left(0.835^{* * *}\right)\end{array}$ & \\
\hline Reporting and codification of CSR & $\begin{array}{l}0.139 \mathrm{~ns} \\
0.589 * * *\end{array}$ & \\
\hline Improved reporting of CSR activity. & $\begin{array}{c}0.297 \mathrm{~ns} \\
\left(0.803^{* * *}\right)\end{array}$ & \\
\hline Improved codification of CSR practice.. & $\begin{array}{c}0.782^{* * *} \\
\left(0.974^{* * *}\right)\end{array}$ & \\
\hline \multicolumn{3}{|l|}{ Affective commitment (based on Bansal et al. 2004) } \\
\hline I believe that my firm has a strong attachment to our partner firm. & & 0.888 \\
\hline I feel that my firm is part of the family of our partner firm. & & 0.928 \\
\hline I believe that my firm has a strong sense of belonging to our partner firm. & & 0.887 \\
\hline \multicolumn{3}{|l|}{ Normative commitment (based on Bansal et al. 2004) } \\
\hline $\begin{array}{l}\text { Even if it were to our advantage, I feel that it would not be right for us to } \\
\text { leave our partner firm. }\end{array}$ & & 0.809 \\
\hline Our partner firm deserves our commitment. & & 0.712 \\
\hline $\begin{array}{l}\text { We would not leave our partner firm because we have a sense of obligation to } \\
\text { them. }\end{array}$ & & 0.840 \\
\hline \multicolumn{3}{|l|}{ Continuance commitment (based on Bansal et al. 2004) } \\
\hline It would be very hard for us to leave our partner firm even if we wanted to. & & 0.830 \\
\hline If we decided to leave our partner firm, there would be too much disruption. & & 0.858 \\
\hline $\begin{array}{l}\text { I believe that we would not have too many options if we decided to leave our } \\
\text { partner firm. }\end{array}$ & & 0.794 \\
\hline
\end{tabular}

Notes:

If not mentioned otherwise, all items were measured on seven-point rating scales, with anchors at $1=$ "strongly disagree" and $7=$ "strongly agree"

$* * * p<0.01$

${ }^{a}$ Outer weights and outer loadings are calculated for two stages of analysis (see Hair et al., 2013, p.233). In the first stage, the repeated indicator approach is used in obtaining the indicator weights for all the lower-order components. In the second stage, these obtained scores are used for the higher-order component. 